\title{
ADSORPTION BEHAVIOUR OF CHEMICALLY MODIFIED CELLULOSE BEARING BENZOTHIAZOLE CHELATING GROUP TOWARDS LEAD IONS FROM WATER BODIES
}

\author{
R. Mahalakshmi ${ }^{1, *}$, K. Preethi ${ }^{2}$, D. Kalaiselvi ${ }^{3}$, M. Manjuladevi ${ }^{4}$, \\ K. Karthik ${ }^{1}$ and Ramalatha Marimuthu ${ }^{5}$ \\ *R \& D Centre, Bharathiar University, Coimbatore, Tamilnadu, India. \\ ${ }^{1}$ Department of Science \& Humanities, Chemistry Division, Kumaraguru College of \\ Technology, Coimbatore, Tamilnadu, India \\ ${ }^{2}$ Department of Civil Engineering, Kumaraguru College of Technology, Coimbatore, \\ Tamilnadu, India \\ ${ }^{3}$ Department of Science \& Humanities, Chemistry Division, Adhitya College of Engineering \\ and Technology, Tamilnadu, India \\ ${ }^{4}$ Department of Science \& Humanities, Chemistry Division, S.N.S College of Technology, \\ Coimbatore, Tamilnadu, \\ ${ }^{5}$ Department of Electronics and Communication Engineering, Kumaraguru College of \\ Technology, Coimbatore, Tamilnadu, India \\ *E-mail: mahalakshmi.r.sci@kct.ac.in
}

\begin{abstract}
The selective removal of $\mathrm{Pb}^{2+}$ ions by chemically modified cellulose hybrid materials have received great consideration because of their superior adsorption capacities as various chemicals, such as mineral and organic acids, bases, oxidizing agents, and organic compounds, have been used for modifications. This work is to synthesize chemically modified cellulose and examine its adsorption capacity towards lead ions from the effluent water by the adsorption studies like $\mathrm{pH}$, contact time, the dosage of the adsorbent, metal ion concentration, temperature and desorption of the adsorbent material.

Keywords: Chemically modified Cellulose, Spectral characteristics, Adsorption Isotherm, Kinetic Studies, Desorption
\end{abstract}

(C) RASĀYAN. All rights reserved

\section{INTRODUCTION}

The growing levels of mobile and soluble heavy metal species is a severe problem, due to their high degree of toxoids ${ }^{1}$. The metals of greater concern are Mining, electroplating, metal processing, battery manufacturing, pesticides, printing, photographic industries, ceramic and glass industries becomes the major sources of heavy metal contamination such as $\mathrm{Al}, \mathrm{Cd}, \mathrm{Co}, \mathrm{Cu}, \mathrm{Pb}, \mathrm{Mn}, \mathrm{Hg}, \mathrm{Ni}$ and $\mathrm{Zn} .{ }^{2}$. The level of heavy metal contamination in water suggested by U. S. Environmental protection agency (EPA) shows that copper, cadmium, zinc and nickel and lead were,1.3, 0.005, 5 and $0.040 .015 \mathrm{mg} / \mathrm{L}$ t respectively ${ }^{3}$. Chemical precipitation, coagulation, ion exchange, solvent extraction, filtration, evaporation, electrolytic processes and photo catalytic degradation ${ }^{4}$ are the variety of treatment methods available to remove metal pollutants from an aqueous media. Fly ash, blast furnace sludge, coffee husks red mud, , areca wastes, , residual slurry, saw dust, microbial biomass, sugar beet pulp pine bark, metal oxides and polymeric resins are the various adsorbents used for the heavy metal removal in aqueous solution ${ }^{5-17}$. The heavy metal removal acquired noticeable attention due to its detrimental effects to recover the aquatic environment. Recent research is concerned with the eco-friendly approach by utilizing the readily available natural and

Rasayan J. Chem., 12(1), 245-250(2019)

http://dx.doi.org/10.31788/RJC.2019.1215001

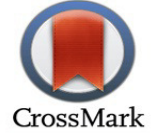


renewable raw materials such as cellulose and its derivatives. Among the various polymers, cellulose has a unique place in heavy metal removal from wastewater. The presence of hydroxyl groups present in cellulose-based derivatives in received great attention. By the periodate oxidation of cellulose which was further oxidized by using mild acidic sodium chlorite ${ }^{18}$ the aldehyde cellulose was prepared The selective removal of $\mathrm{Pb}^{2+}, \mathrm{Cu}^{2+}$ and $\mathrm{Ni}^{2+}$ heavy metals by chemically modified cellulose hybrid materials ${ }^{19}, 2,3-$ dicarboxy cellulose ${ }^{20}$, Cellulose graft copolymer containing carboxylic group ${ }^{21}$, Acrylamide grafted cellulose ${ }^{22}$, have received great consideration. This work is to synthesize the chemical modification of cellulose adsorbent and examine its metal ion uptake by using $\mathrm{Pb}^{2+}$ ions. The metal ion adsorption for the concurring removal of the metal ions has been evaluated by cellulose-based adsorbent (Cell-ABT). The various metal adsorption studies like solution $\mathrm{pH}$, contact time, dosage, for the adsorbent, temperature metal ion concentration, desorption studies of the sorbent material have been measured.

\section{Chemicals and Reagents}

\section{EXPERIMENTAL}

All the chemicals and reagent used for the experiment and the analysis were of an analytical grade. $N, N$ dimethyl aniline (Fluka), sodium meta periodate (Sigma Aldrich), Cellulose (Loba), and $\mathrm{Pb}\left(\mathrm{NO}_{3}\right)_{2}$, salts were collected from Aldrich-Sigma Chemical, India. By dissolving the appropriate amount of the respective salts in distilled water from the stock solutions of $1000 \mathrm{mg} / \mathrm{L}$ the standardized lead ions were prepared.

\section{Synthesis of Chemically Modified Cellulose (Cell-ABT)}

Cellulose bearing Schiff base with a chemically modified form with benzothiazole chelating groups was synthesized by condensation of dialdehyde cellulose with 2-aminobenzothiazole. The p-aminobenzothiazole (1.5g) dissolved in $20 \mathrm{ml}$ of $\mathrm{N}, \mathrm{N}$ - dimethylformamide (DMF) was mixed with dialdehyde cellulose $(0.5 \mathrm{~g})$ and $\mathrm{Con} . \mathrm{HCl}$ was added by few drops to act as a catalyst and constantly stirred at $70^{\circ} \mathrm{C}$ for $5 \mathrm{~h}$. The brown gel (p-aminobenzothiazole) is obtained was poured in absolute ethanol. The above-formed product was refreshed, washed and drained several times with hot water and under vacuum, it was dried.

\section{RESULTS AND DISCUSSION}

\section{Schematic Synthesis and Characterization of Cell-ABT}

Synthesis of 2,3-Dialdehyde Cellulose and chemically modified Cellulose (Cell-ABT) are represented in Scheme-1.

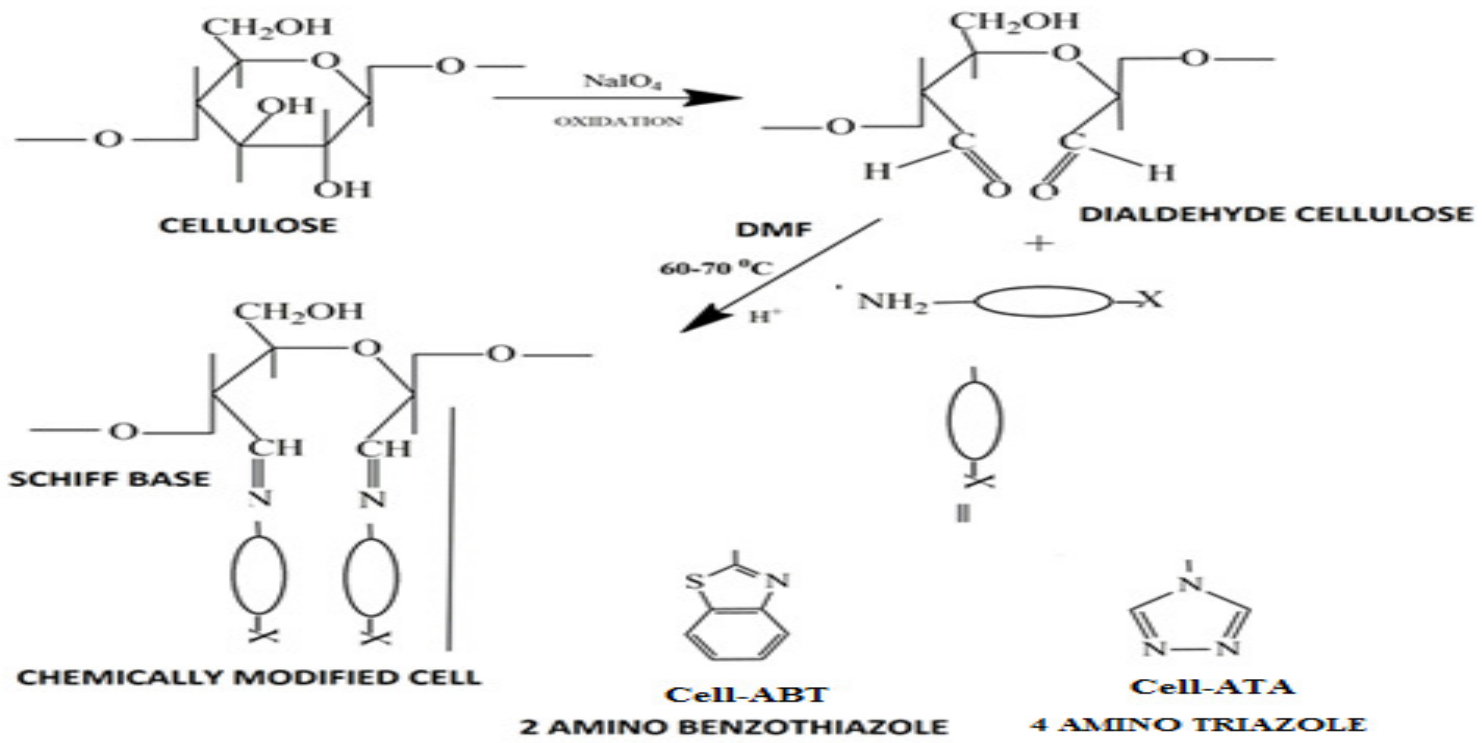

Scheme-1: Synthesis of Monomer 2, 3-Dialdehyde Cellulose and Polymerization of Chemically Modified Cellulose (Cell-ABT) 
The -OH stretching frequency appeared at $3501 \mathrm{~cm}^{-1}$, and also the $-\mathrm{CH}=\mathrm{N}$-stretching frequency appeared at $1626 \mathrm{~cm}^{-1}$ and the C-N stretching frequency appeared at $1453 \mathrm{~cm}^{-1}$. The formation of pendent benzothiazole groups in the chemically modified cellulose was confirmed by the peak at $1155 \mathrm{~cm}^{-1}$ for $\mathrm{C}-\mathrm{S}$ - stretching frequency of benzothiazole groups given by FT-IR Spectrum details.

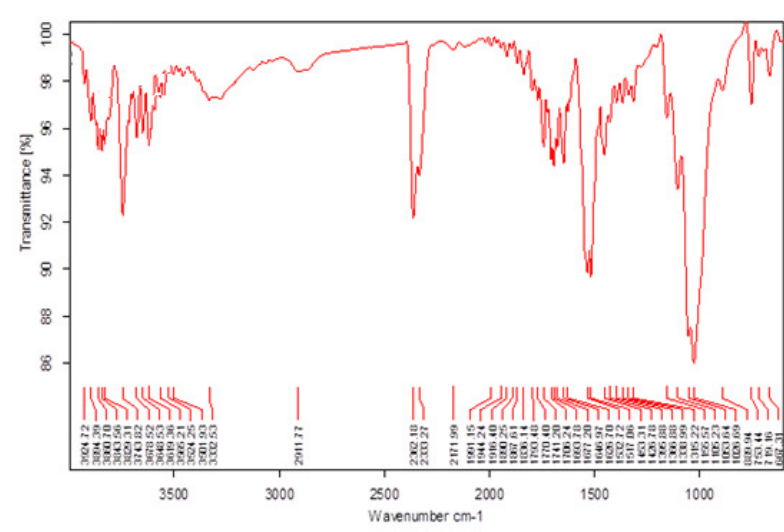

Fig.-1: FT-IR Spectrum of Cell-ABT

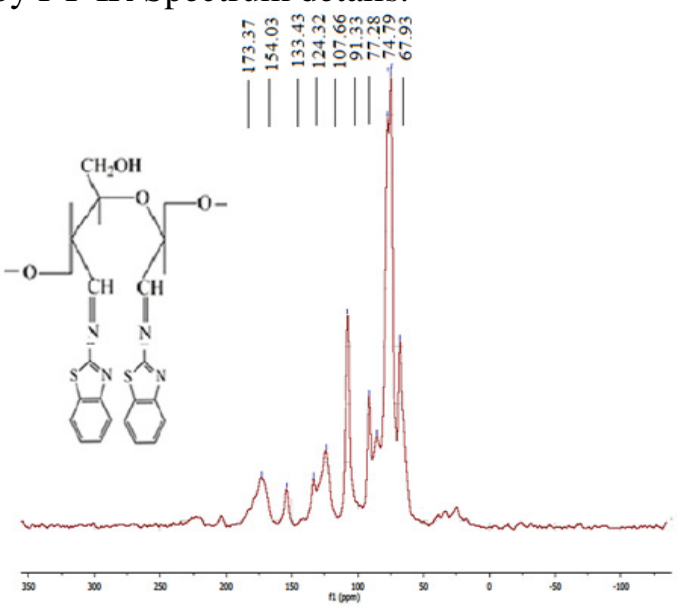

Fig.-2 ${ }^{13} \mathrm{C}$ NMR Spectrum of Cell-ABT

When compared to the native adsorbent synthesized the ${ }^{13} \mathrm{C}$ CP-MAS NMR spectrum of chemically modified cellulose (Cell-ABT) shows remarkable additional peaks of the benzothiazole pendent groups. The Cellulose carbon shows the $\delta$ values between 107 to $67 \mathrm{ppm}$. The peak at $\delta$ value of 133-124 is accounted for the aromatic ring carbons. The peak with $\delta$ value of 154 shows the presence of thiazole carbon. The carbon $-\mathrm{CH}=\mathrm{N}$ - appeared at $\delta$ value of $173 \mathrm{ppm}$. The formation of chemically modified cellulose (Cell-ABT) was confirmed by the above observations.

The asymmetric surface and open pore structure is shown in the SEM image of the Cell-ABT, shows the high internal surface area present in the surface of the adsorbent. The surface area of the treated CellABT with metal ions shows the more evenness, after adsorption is given in Fig.-3. The EDAX analysis which confirms the adsorption of $\mathrm{Pb}$ (II), ions onto the Cell-ABT adsorbent.(Fig.-4 and 5) and the smoothness of the surface is due to the adsorption of the metal ions on the Cell-ABT adsorbent.
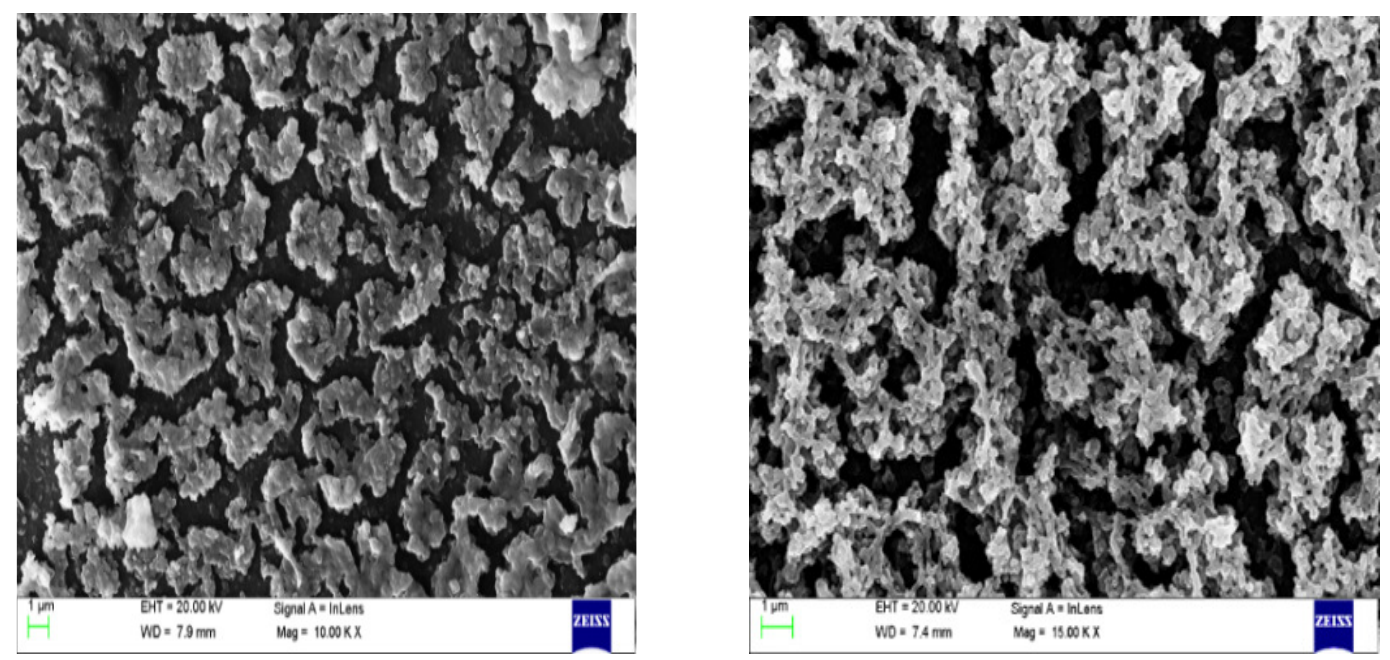

Fig.-3: SEM images of (A) Cell- ABT (B) Pb(II) Loaded Cell- ABT

\section{Heavy Metal Adsorption Studies of Cell-ABT}

The percentage of metal ion removal is highly influenced by solution $\mathrm{pH}$ which is shown in Fig.-6. The removal percentage of the $\mathrm{Pb}(\mathrm{II})$ ions increases with an increase in $\mathrm{pH}$ level from 3.0 to 6.0. It is visible that the capacity of the adsorption increases with $\mathrm{pH}$ up to 6 and slow down above this value. The metal 
RASĀYAN J. Chem.

Vol. 12 | No. 1 |245 - 250| January - March | 2019

ions get precipitated as its hydroxides at higher $\mathrm{pH}$ values $(>6)$, hence, in all batch adsorption experiments, an optimum $\mathrm{pH}$ value of 6 was fixed. This could be due to the act active sites was higher. ${ }^{23}$
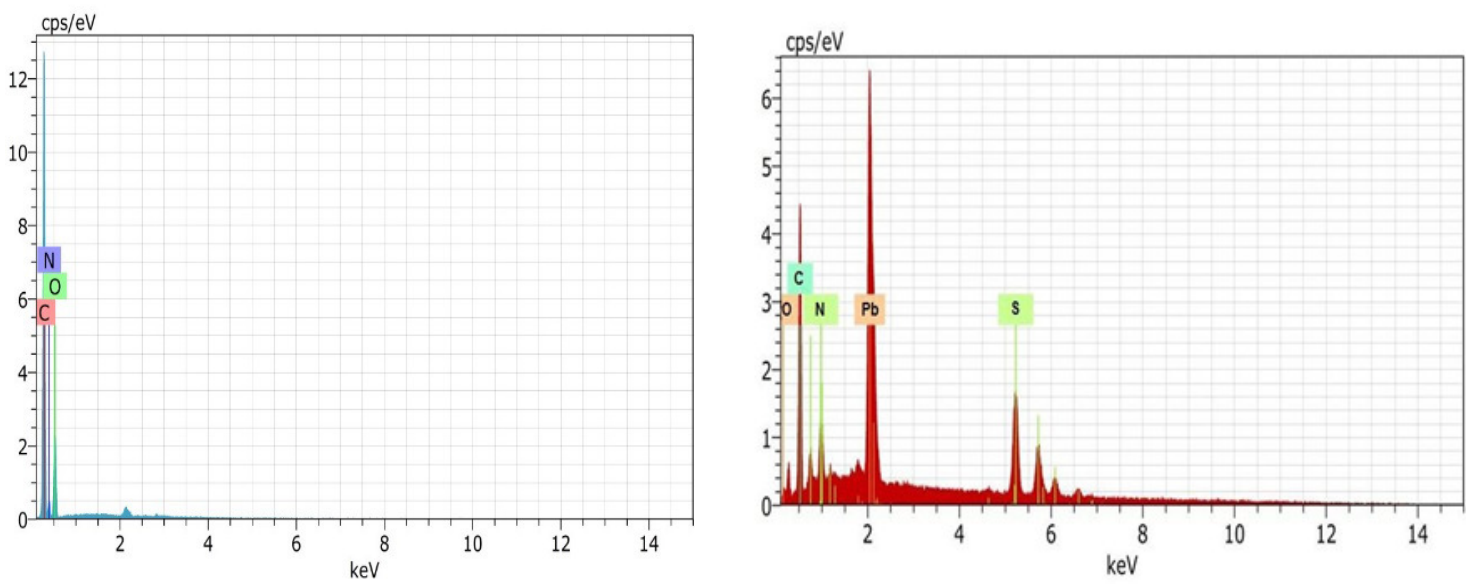

Fig.-4: EDAX Spectra of Cell-ABT Fig.-5: EDAX Spectra of Pb (II) ions loaded

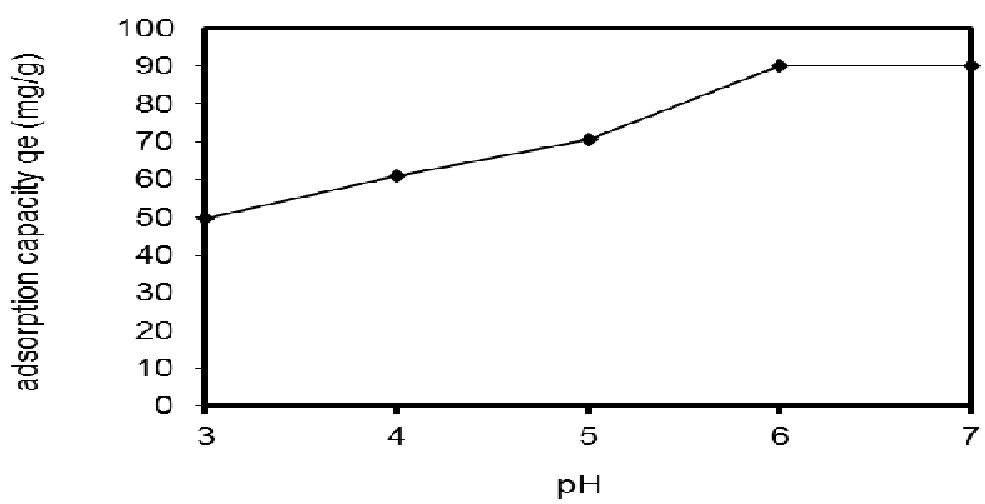

Fig. -6: Effect of $\mathrm{pH}$ onto $\mathrm{Pb}(\mathrm{II})$, Metal Ions by Cell-ABT

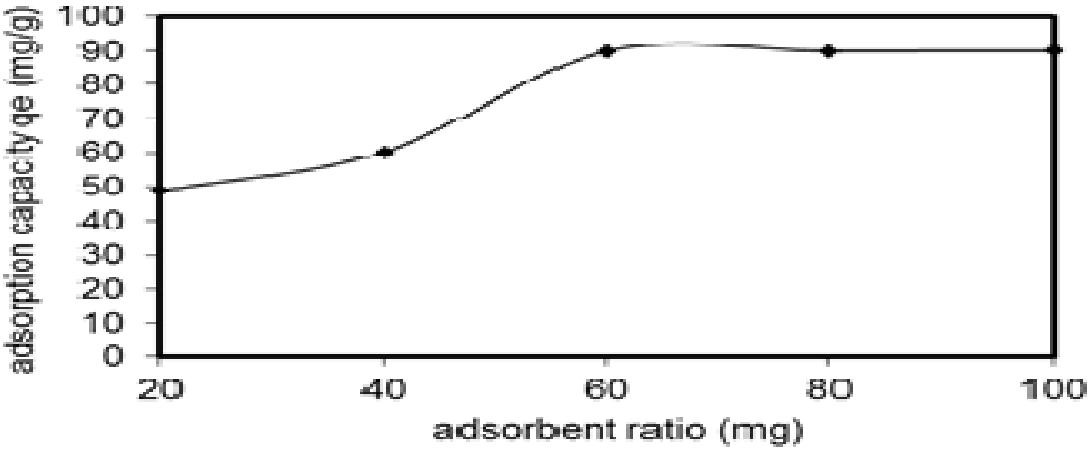

Fig.-7: Effect of Adsorbent Dose on to Pb(II) Metal Ion by Cell-ABT

As the metal ion concentration strongly influence the metal sorption from the solution the adsorbent provides binding ${ }^{24}$.The availability of more sites makes the metal ion adsorption as a considerable one when compare ${ }^{\mathrm{d}}$ to the low adsorbent dosages. ${ }^{25}$ The maximum time of $60 \mathrm{~min}$ is fixed as the adsorption completes at the time period. During the former stages of adsorption period it is maximum and later it came down due to the saturation of adsorbent. ${ }^{26,27}$

The adsorption kinetics gives information on adsorption mechanism which is utilized to the optimization of the adsorption process. One of the most important parameters was taken as time as it has a significant

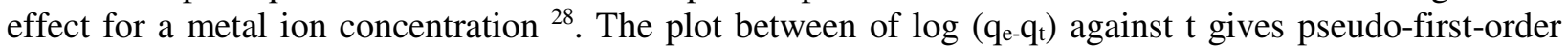
equation which was determined. The $\mathrm{q}_{\mathrm{e}}$ and $\mathrm{k}_{2}$ were calculated from the slope and intercept of the plots, for the pseudo-second-order model. Ho et al ${ }^{29}$ describe that the linearity of the plots suggests the 
chemisorptions process. The high correlation coefficients $\left(\mathrm{R}^{2}\right.$ values $\left.>0.990\right)$ suggest the adsorption process follows pseudo second-order kinetic model. The diffusion of ions leads to more transfer of lead ions towards binding sites because of low $\mathrm{k}$ values. ${ }^{30}$

The intra particle diffusion model is given by, Weber and Morris where $\mathrm{t}$ is the time, and $\mathrm{k}_{\mathrm{p}}$ is the Intraparticle diffusion kinetic rate constant $\left(\mathrm{mg} / \mathrm{g} / \mathrm{min}^{1 / 2}\right)$ calculated from the linear plots $\mathrm{q}_{\mathrm{t}}$ against $\mathrm{t}^{1 / 2}$ using the experimental data. As the difference in the mass transfer rate between the initial and final stages of adsorption deviates the straight line to pass through the origin.

The heterogeneous distribution of the process of adsorption which varies with surface coverage in liquidsolid adsorption process was given by Elovich equation ${ }^{31}$, where the $\alpha$ and $\beta$ values were estimated from the plot of " $\mathrm{q}$ " against "In t". The Elovich kinetic model gives the best- fit to experimental data for the lead ions means the occupation of adsorption sites is proportional to the square number of vacant sites, because the pseudo-second-order model is based on a second-order mechanism ${ }^{32}$

The adsorption mechanism formulated by Langmuir is between physical forces and it was assumed that all adsorption sites have good affinity with an adjacent site ${ }^{33,34}$. The metal ion concentration plays as major role as there is competition with the active sites shown in the adsorbent ${ }^{35}$. The value of $\mathrm{R}_{\mathrm{L}} 1$ between $0-1$ indicates the very good adsorption of $\mathrm{Pb}$ (II) metal ions on to Cell-ABT.

The relationship between the heterogenous surfaces are given by Freundlich isotherm.. Where $\mathrm{k}_{\mathrm{F}}$ is the Freundlich constant $(\mathrm{dm} 3 / \mathrm{g})$ and $\mathrm{n}$ is the Freundlich exponent. A greater value of $\mathrm{k}_{\mathrm{F}}$ indicates a higher adsorption capacity. The higher $\mathrm{R}^{2}>0.9$ values indicate that the metal ions adsorption if the favorable one. The $\mathrm{n}$ value between 1 and 10 indicates very good adsorption of the $\mathrm{Pb}(\mathrm{II})$, metal ions towards metal adsorbent. The presence of chemisorptions is given by the $1 / \mathrm{n}$ value and above this shows the cooperative adsorption. ${ }^{36}$

The graph plotted between Ce/qe versus Ce $\beta$ gives the Redlich-Peterson isotherm constant value. The Regression values to the lead ions to the metal adsorbent was found to follow the Redlich-Peterson isotherm equation as the degree of heterogeneity can be utilized for high solute concentrations. ${ }^{37}$

The adsorbent and adsorbate interaction was given by Temkin isotherm. The Temkin constants $\mathrm{B}\left(\mathrm{mg} \mathrm{g}^{-1}\right)$ and $\mathrm{A}\left(\mathrm{L} \mathrm{g} \mathrm{g}^{-1}\right)$ be determined by a plot of qe versus $\mathrm{lnCe}$. Due to the heat of adsorption molecules decreases linearly when the adsorbent surface was covered ${ }^{38}$.

Gibbs free energy of adsorption $\left(\Delta \mathrm{G}^{\circ}\right)$, the enthalpy change $\left(\Delta \mathrm{H}^{\circ}\right)$, and the entropy change $\left(\Delta \mathrm{S}^{\circ}\right)$ such thermodynamic parameters were studied. The adsorption of lead metal ions decreases with a temperature towards adsorbent .The spontaneity and the feasibility of the of the adsorbent shown by The negative value of $\Delta \mathrm{G} .{ }^{39}$ and the free energy value increases show that there is a good driving for the metal ion binding process. The $\Delta \mathrm{H}^{\circ}$ values show that the adsorption process is feasible. The negative entropy suggests that the solid/solution interface system during this adsorption process is exothermic.$^{40}$

\section{Desorption Studies of Cell-ABT}

The desorption studies were carried out for the lead ions towards the Cell-ABT adsorbent reveals that it can be utilized so many times and can be regenerated easily

\section{CONCLUSION}

Cellulose with chemical modification is utilized for the removal of heavy from aqueous solutions effectively. From the FT-IR studies, the active sites in the chemically modified cellulose adsorbent with Schiff base were evidenced. In Cell- ABT, the $-\mathrm{CH}=\mathrm{N}$ - stretching frequency appeared at $1626 \mathrm{~cm}^{-1}$, was shifted to $1646 \mathrm{~cm}^{-1}$. The $-\mathrm{C}-\mathrm{N}$ - stretching frequency appeared $1453 \mathrm{~cm}^{-1}$, is also shifted to $1463 \mathrm{~cm}^{-1}$. The $-\mathrm{C}$ $\mathrm{S}$ - stretching frequency of the Cell-ABT, appeared at $1155 \mathrm{~cm}^{-1}$ has undergone a significant change in the $\mathrm{Pb}$ (II) metal ion adsorbed Cell-ABT. From the above observations, the hetero atoms $\mathrm{N}$ and $\mathrm{S}$ of the chelating groups have a responsible for the formation of the co-ordinate bond between the adsorption sites with the metal ions. The isotherm studies confirmed that the experimental data follow the pseudo-secondorder kinetic model and the Langmuir model which evidenced that the adsorption process is spontaneous and exothermic in nature $(\Delta \mathrm{H}<0)$.It shows very good complexation properties towards the lead metal ions present in the waste water. The low cost, the green metal adsorbent may serve as an efficient adsorbent for the remediation of heavy metals from the aquatic environment. 
RASĀYAN J. Chem.

Vol. 12 | No. 1 |245 - 250| January - March | 2019

\section{REFERENCES}

1. A.M. Herica, F. Natalia, T.A. Lelix, G.and Yoshilaka, Cellulose., 19, 913(2012), DOI:10.12732/ijpam.v117i8.22

2. M. Ellchi, and K. Tetsuo, J. Appl. Polym. Sci., 29, 2289(1984), DOI:10.1002/app.1984.070290705

3. G. Gamze, G. Gulten and O. Saadel, J. Appl. Polym. Sci., 90, 2034(2003), DOI:10.1002/app.12728

4. C. Shiyan, S. Wei, Y. Feng, and W. Huaping, Polym.Bull., 63, 283(2009).

5. M. S. Bayrakc1, M. Ertul and M. Yilmaz. Tetrahedron.,65, 7963(2009).

6. M.A.Ahmad and N.K Rahman, Chem. Eng. J., 170, 154(2011), DOI:10.1016/j.cej.2011.03.045

7. V.V Konovalova, G.M. Dmytrenko, R.R. Nigmatullin, M.T. Bryk and P. Gvozdyak, Enzyme Micro.,Technol, 33, 899(2003), DOI:10.1016/S0141-0229(03)00204-7

8. Li, W. Yue, Q. Tu, P. Ma, Z. Gao, B. Li and J. Xu, Chem. Eng. J., 178, 197(2011).

9. G.Vazquez, M.S.Freire, J. Gonzalez-Alvarez and Antorrena, G. Desalination., 249, 855(2009).

10. A.Vazquez - Morillas, M.Vaca-Mier, M and P.J Alvarez. Eur. J. Soil Biol., 42, 99(2006).

11. J.C .Igwe, A.A. Abia and C. Ibeh, Int. J. Environ. Sci. Technol., 5, 83(2008).

12. N.Sharma, K.Kaur, and S. Kaur. J. Hazard. Mater., 163, 1338(2009), DOI: 10.1016/j.jhazmat.2008.07.135

13. S. Azizian, M. Haerifar and M. Bashiri, Chem. Eng. J., 146, 36(2009).

14. Y.Nuhoglu, and E . Oguz, Biochem., 38, 1627(2003), DOI:10.1016/S0032-9592(03)00055-4

15. M. Mukhopadhyay, S. B. Noronha, and G.K. Suraish Kumar, Bioresour. Technol., 98, 1781(2003).

16. P. SenthilKumar, S. Ramalingam, S.V. Sathyaselvabala , S. Dinesh Kirupha and S. Sivanesan,. Desalination ., 266, 63(2011).

17. Z. Aksu, and I. A . Isoglu, Process Biochem., 40, 3031(2005).

18. R. Mahalakshmi, L. Ravikumar and K. Rathina, International Journal of Pure and Applied Mathematics. , 117(8), 109(2017)

19. S. L. Sun and A. Q. Wang, Sep. Purif. Technol., 49, 197(2006).

20. M.V. Dinu and E.S .Dragan, E.S. React. Funct. Polym., 68, 1346(2008).

21. A.S. Ozcan, O. Gok, and A. Ozcan, J. Hazard. Mater.,161, 499(2009).

22. A.R. Cestari, E.F.S. Vieira, and C.R.S. Mattos, C.R.S. J. Chem. Thermodyn., 38, 1092(2006).

23. A,Y. Dursun, Biochem. Eng. J., 28(2), 187 (2006), DOI: 10.1016/j.bej.2005.11.003

24. D. Kumar, J.P. Gaur J.P. Bioresour. Technol., 102, 2529(2011)

25. H.L.H. Chong,P.S, Chia and M.N. Ahmad Bioresour. Technol., 130, 181(2013)

26. E. Igberase and P. Osifo, Journal of Industrial and Engineering Chemistry., 26, 340(2015).

27. A.Shanmugapriya, M.Hemalatha, B. Scholastica and T.B. Augustine Der Pharma Chemica., 5(3), 141(2013)

28. R. Mahalakshmi, K. Rathina and L. Ravikumar, Rasayan Journal of Chemistry., 10(1), 286(2017), DOI: $10.7324 /$ RJC.2017.1011633

29. Y.S. Ho, D. A. Waste and J. Forster, C.F. Wat. Res., 29, 1327(1995).

30. C.O. Ijagbemi, M.H. Baek and D.S. Kim. J. Hazard. Mater., 166(1), 538(2009).

31. C,W.Cheung, J.F. Porter, G. McKay, Water Res., 35, 605(2001).

32. S.F. Al-Jomaa, S. F. Statistical Design and Analysis of Experiments. Society for Industrial, and Applied Mathematics., 12 ,161(2011).

33. M.Sathishkumar, A.R. Binupriya, K. Vijayaraghavan S, and Yun. J. Chem. Tech. Biotech., 82, 389 (2007).

34. K. Vijayaraghavan, T.V.N. Padmesh, K. Palanivelu and M.Velan, J. Hazard. Mate.r, 133, 304 (2006), 10.1016/j.jhazmat.2005.10.016

35. G. Kalyani , Y. Prasanna Kumar and P. King, Rasayan J. Chem., 9(3), 510(2016).

36. K.Y. Foo, and B.H. Hameed, Chem. Eng., 156, 2(2010), DOI:10.1016/j.cej.2009.09.013

37. E. Guibal, C. Milot, and M. Tobin, Ind. Eng. Chem. Res., 37,1454(1998) DOI: 10.1021/ie9703954

38. J. S. Piccin, G. L. Dotto, and L. A. A. Pinto, J. Chem. Engg, 28, 295(2011).

39. Z. Zawani C.A. Luqman and S,Y. Thomas, European Journal of Scientific Research., 37,63(2009).

40. M. F. Ahmad, S. Hayda and T. A., Int. Biodeterioration Biodegrad., 83,119(2013).

[RJC-5001/2018] 